\title{
PALAEOGEOGRAPHICAL RECONSTRUCTION AND MANAGEMENT CHALLENGES OF AN ARCHAEOLOGICAL SITE LISTED BY UNESCO: THE CASE OF THE LETOON SHRINE IN THE XANTHOS PLAIN (TURKEY)
}

\author{
ERIC FOUACHE \\ Université de Paris-Sorbonne, Paris, France \\ Emilie ECOChard, CATHerine KuZucuoĞLu \\ Université de Paris Est Créteil, Laboratoire de géographie physique, Meudon, France \\ Nathalie CARCAud \\ Agrocampus ouest Centre d'Angers, Institut National d'Horticulture et de Paysage, Angers, France \\ MEHMET EKMEKÇI \\ University of Hacettepe, Department of Hydrogeology, Ankara, Turkey \\ InAN Ulusoy, AtTila ÇineR \\ University of Hacettepe, Department of Geology, Ankara, Turkey \\ JaCQues Des COURTILS \\ Université de Bordeaux 3, Pessac, France
}

Manuscript received: February 23, 2012

Revised version; March 6, 2012

Fouache E., Ecochard E., KuzucuoĞlu C., Carcaud N., Ekmekçı M., Ulusoy I., Robert V., Çiner A. \& Des Courtils J., 2012. Palaeogeographical reconstruction and management challenges of an archaeological site listed by UNESCO: the case of the Letoon shrine in the Xanthos Plain (Turkey). Quaestiones Geographicae 31(1), Bogucki Wydawnictwo Naukowe, Poznań 2012, pp. 37-49. 5 Figs., 1 Tab. DOI 10.2478/v10117-012-0002-z, ISSN 0137-477X.

Abstract. During the Hellenistic period, Xanthos and Letoon were respectively a large city and an important shrine in Lycia. Questions still remain about the geography of the Eşen Çayı delta during the first millennium BC: what were the features of the landscape surrounding the Letoon shrine? Where did the riverbed lie? Our analysis is based on a reconstruction of the geomorphological dynamics at work during the Holocene. These are then compared with historical, archaeological and literary sources. Sedimentary sampling shows that a marine 
bay was gradually closed during the formation of a coastline spit, which led to the development of a lagoon system. Lagoons and marshes remained predominant characteristics of the plain over a long period. A branch or a former channel of the Eşen Çayı was discovered close to the Letoon shrine. In recent decades, authorities, as well as UNESCO, are now making an effort to manage palaeoenvironmental reconstructions in their promotion of the tourist potential of archaeological sites. We propose a management project for the Letoon site.

KEY wORDS: geoarchaeology, archaeo-geomorphosite, Holocene, deltaic progradation, Turkey

Eric Fouache, Université de Paris-Sorbonne, IUF, UMR 81185 ENeC, 191 rue Saint Jacques, 75005 Paris, France, e-mail: eric.g.fouache@wanadoo.fr

\section{Introduction}

The two archaeological sites of Xanthos and Letoon lie in the delta plain of the river Xanthus - nowadays referred to as Eşen Çayı (Fig. 1) - in southwest Turkey. The Eşen Çayı valley is a a graben that has been active since the end of the Pliocene (Bousquet \& Péchoux 1981, Kayan 1999). The river is flanked by the limestone ranges of the Lycian Taurus Mountains, and formed by the Lycian thrust sheet displaced during the Miocene period.

The sites of Xanthos and Letoon lie in a very mobile environment. The Xanthos plain was formed gradually by the Xanthus River during the Holocene. The extensive coastal building of dunes remain to a large extent mobile, especially in those places where the efficiency of the greening over carried out in the 1960s has been damaged by an increase in animal grazing. The movement of the dunes goes from west to east and is determined by the currents of the longshore drift that flow NW-SE as well as by the W-E direction of the prevailing winds.

The city of Xanthos, located on a rock promontory on the left bank of the river, looks down on the apex of the delta. According to Strabo's Geography $(14,3)$, it was the largest city in Lycia. Five kilometres away downstream stood the imposing, federal shrine of Letoon, which was built against a limestone hill on the right bank of the river. The plain also boasts Lycian fortresses and the mighty port of Patara in the southeast (Fig. 1), built during the Hellenistic period but reaching its hey-day in Roman times (des Courtils 2003).

The architectural remains bear witness to a history rich in a variety of cultural influences, starting with the arrival of the first inhabitants during the $7^{\text {th }}$ century BC. However, the environmental con- text prevailing at the time of the first settlement of the site also determined their characteristics as well as their architectural and spatial evolutions (Jacob 1995). Profound changes have taken place in the morphology of the plain since the Hellenistic period. Archaeologists studying the two sites cannot work on the assumption that the landscape in which they now lie has remained unchanged ever since the arrival of the first settlers during the $7^{\text {th }}$ century BC. Therefore both historians and archaeologists are bound by the necessity of reconstructing the environmental dynamics at work during the Holocene and, increasingly, this is being achieved by calling in cross-disciplinary research teams, made up of geographers as well as Quaternary and palaeoenvironmental specialists, working in a geoarchaeological perspective. In recent decades, this approach has become widespread the archaeological sites of the Mediterranean and elsewhere, but the results of these reconstructions are too seldom put to good use when promoting the tourist appeal of the archaeological sites (Fouache \& Rasse 2009). Yet the case of the Letoon shrine is one where the Turkish authorities have requested proposals for an awareness raising campaign to be launched.

\section{Methodology: the choice of the geoarchaeological approach}

Our research was carried out in a geoarchaeological perspective following lines of reasoning introduced by Vita-Finzi (1969) and later developed by Rapp \& Hill (1998) or Brown (1997), in order to define the evolution of the landscape in link with human settlements (Fouache 1999, 2003). The deltaic plains of the Mediterranean lend themselves particularly well to this type of 


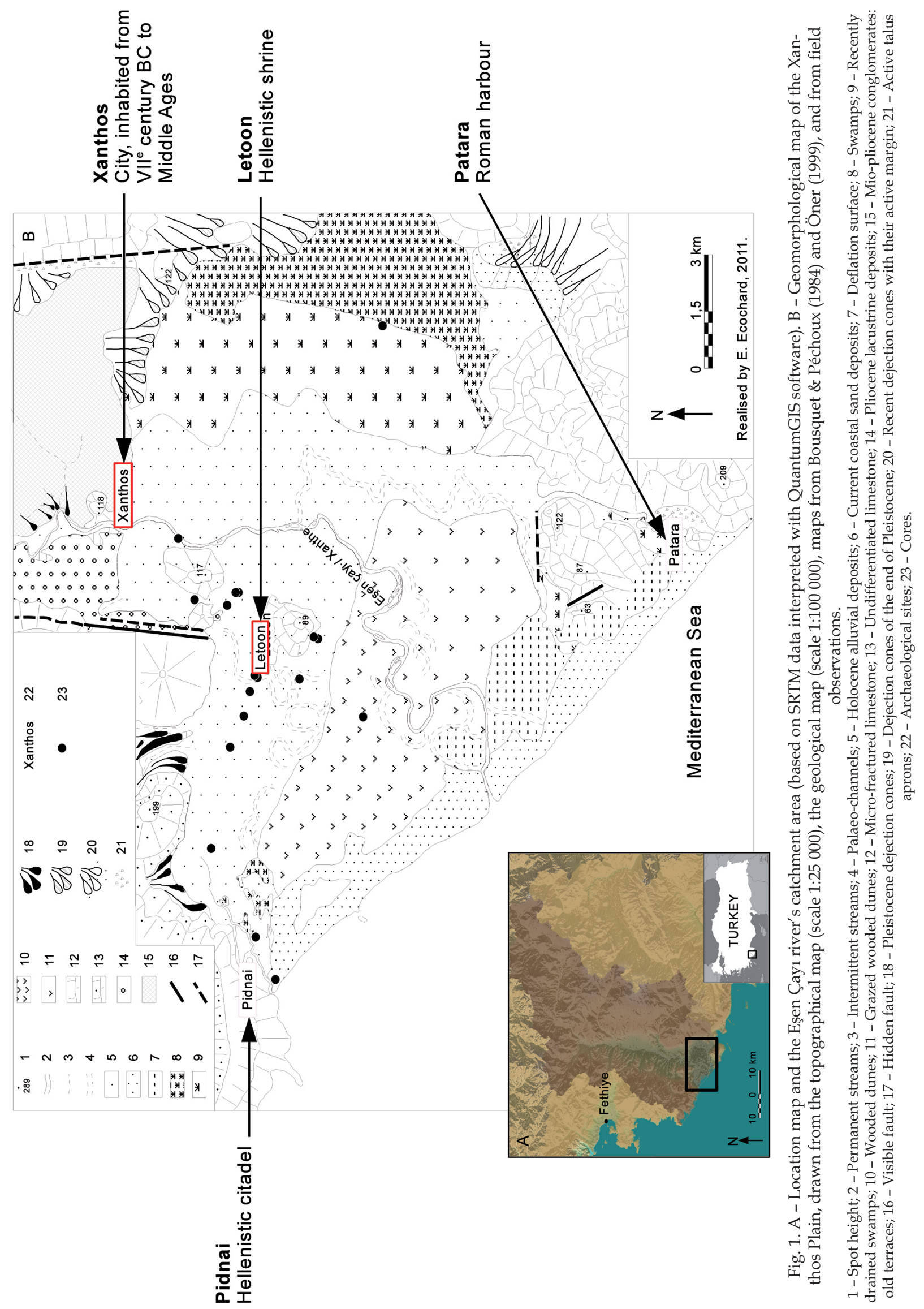


research. During the Holocene they underwent considerable changes in their coastline and, for this reason, provide excellent records of the natural or anthropogenic processes at work in their formation (Brückner et al. 2005, Fouache \& Pavlopoulos 2005). The multidisciplinary approach involves cross-referring and comparing geomorphological, palaeoenvironmental and geographical data with archaeological, historical and literary data. The geomorphological data have been obtained from geophysical prospecting consisting of 14 transects of electrical resistivity and 21 samples taken by a hydraulic piston coring device. All the electrical transactions, as well as most of the cores were obtained from the western part of the plain, around the site of Letoon. The geomorphological evolution of this area plays a decisive role in the understanding of the relationship that could have existed between the shrine and the city of Xanthos, as well as with the rest of Lycia, especially on the subject of accessibility to the site and human mobility throughout the plain. Analyses were carried on in the Laboratory of physical geography in Meudon (France). Measurement was made of magnetic susceptibility on 9 cores. This analysis was undertaken in order to identify or confirm changes in sedimentary samples spotted earlier during an initial visual description of the sediments, and to correlate other surveys. The measure was taken with a Bartington MS2 device, associated with the MS2C probe. On three cores, chosen for their representativity (deepest cores, around the Leto shrine), we measured the amounts of carbonates and organic material, sampling every $20 \mathrm{~cm}$. This analysis was carried out in view of identifying or confirming changes in sedimentary samples spotted earlier during an initial visual description of the sediments. The aim of the sampling was also to determine what the environmental conditions were at the time of deposition. In addition, analysis was made of a deposit of volcanic debris present in core L-XII in order to identify which volcanic eruption it came from. The geochemical signature of the sample was analysed by B. Caron from Department of Earth Sciences, University of Pisa. Fifteen radiocarbon datings, from three cores, have been sent to the Center of radiocarbon dating of Lyon-I University. Unfortunately, only one provided meaningful informa- tion, due to the lack of organic materials and the deltaic context of other samples. No particle size analysis have been made: the results would have been redundant with those of the organic and carbonates contents. Moreover, this study seeks to define the main stages of the Xanthos plain's construction and not to reveal small events, like flood processes, which could have had a local impact on the environment. Besides the sedimentary study, the SRTM (Shuttle Radar Topography Mission) data has been fed into a GIS software to visualize micro-topography, and, in particular, the stages of the delta's progradation.

The literary references are taken from primary sources and include accounts by classical authors such as Strabo's Geography (Book 14), Plutarch's Concerning the Virtues of Women (Morals, volume I), Herodotus' Histories (Volume I, Book I), Arian's Anabasis Alexandri (Volume I, Book I) and Ovid's Metamorphoses (Volume II, Book VI), as well as the tales of mainly Western travellers, who managed to visit Lycia in the $19^{\text {th }}$ century, such as Beaufort (1818), Fellows (1840, 1852), Spratt \& Forbes (1847), and also Texier (1839-1849). Stories from ancient mythology and the campaign logs of Greek or Roman generals also provide some information about the ancient geography of the relevant areas, allowing us to understand how the environment was viewed at the time and which aspects of the scenery were used as landmarks necessary to the reader. The value of modern travellers' tales lies in their description of landscapes as they appeared long after the ancient sites had been deserted, but before the considerable changes introduced by the developments in agriculture and tourism of the $20^{\text {th }}$ century: these tales are witnesses to landscapes as they were when natural processes prevailed. Our suggestions for boosting the image of the sites are taken from guidelines laid down by Pelfini et al. (2009) and Zouros (2009).

\section{Results}

In the west part of the plain, seven cores were drilled along a line beginning at the marshes lying in the northwest of the plain and running to the hill of the Letoon site (Fig. 2). The deepest core (L-XII: $9.50 \mathrm{~m}$ ) is our point of reference when de- 


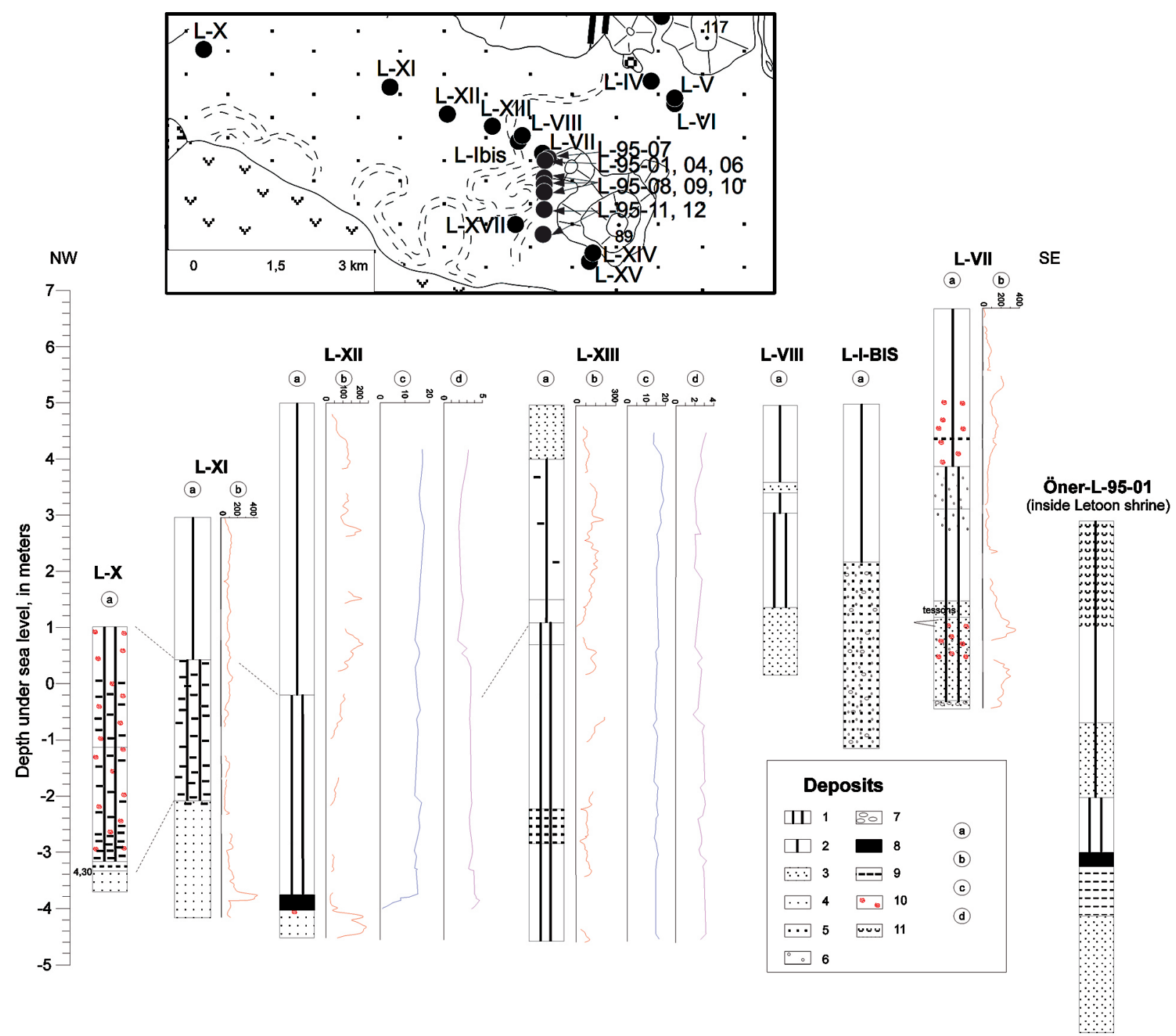

Fig. 2. Cores realised at the west of the Letoon shrine, supplemented by those made by Öner (1999).

1 - Clay; 2 - Silt clay; 3 - Silt; 4 - Fine sand; 5 - Coarse sand; 6 - Gravels; 7 - Pebbles; 8 - Ash; 9 - Organic matter; 10 - Malacofauna; 11 - Pottery; a - Facies; b - Magnetic susceptibility (SI); c - Carbonates content (\%); d - Organic matter content (\%).

scribing the successive environments. The sediment found in the lower part of the core is made up of grey-black sands of marine origin containing Cerastoderma glaucum bivalves and Potamides conicus gastropods belonging to a lagoon environment. These lagoon deposits are covered with a thick, plastic, grey layer of clay. This clay is characterized by low organic matter content, suggesting the presence of marine salt waters or oligotrophic conditions caused by alluvial processes. Tawny-coloured sandy-silt deposits lie at the top of the sample. The magnetic susceptibility results need careful interpretation. In particular, we did not keep the measures of disturbed sediments, which explain the large number of breaks in curves. Values decrease near the ends of the cores' drives. In these conditions, changes in values are rarely clear. But what clearly appears is that grey clay record lower values than orange silt. In core L-XII, as well as in drillings carried out by Öner (1999), volcanic ash was found to be present. This marks the transition from the lagoon to the marshland context of core L-XII. The geochemical signature of a sample analysed by B. Caron from Department of Earth Sciences, University of Pisa, and taken from the tephra of core L-XII is very similar to ashes identified as Z2 volcanic debris from the last major eruption of Santorini in 3300 cal. BP (Aksu et al. 2006). This result was confirmed by radiocarbon datings car- 
Table $1.14^{\mathrm{C}}$ dating results (conducted through the center of radiocarbon dating located in Lyon) compared with the dating in the survey L-1995-01 realised by Öner (1999).

\begin{tabular}{|c|c|c|c|c|c|c|}
\hline Core Id & $\begin{array}{c}\text { Coordinates (in } \\
\text { UTM, Zone 35 } \\
\text { North Hemisphere - } \\
\text { WGS84) }\end{array}$ & $\begin{array}{c}\text { Depth from } \\
\text { surface } \\
\text { (in meters) }\end{array}$ & Sample type & $\begin{array}{c}\text { Dating } \\
\text { Method }\end{array}$ & $\begin{array}{c}\text { Age } \\
\text { (14C BP) }\end{array}$ & $\begin{array}{c}\text { Calibrated } \\
\text { age (BC) }\end{array}$ \\
\hline L-XII & E 704520/N 4023652 & $1.580-1.600$ & Charcoal dust & & Cancelled & Cancelled \\
\hline L-XII & - & $2.035-2.065$ & Charcoal dust & AMS & $7,065 \pm 30$ & 6,005 to 5,893 \\
\hline L-XII & - & $4.290-4.320$ & Charcoal dust & & Cancelled & Cancelled \\
\hline L-XII & - & $4.570-4.605$ & Charcoal dust & & Cancelled & Cancelled \\
\hline L-XII & - & $5.420-5.450$ & Organic clay & AMS & $5,920 \pm 30$ & 4,844 to 4,721 \\
\hline L-XII & - & $6.930-6.960$ & Organic clay & AMS & $6,630 \pm 30$ & 5,622 to 5,513 \\
\hline L-XII & - & $8.735-8.760$ & Organic silt & AMS & $4,495 \pm 30$ & 3,349 to 3,037 \\
\hline L-XII & - & $8.830-8.850$ & Organic silt & AMS & $4,390 \pm 30$ & 3,093 to 2,914 \\
\hline L-XII & - & $9.020-9.050$ & Organic silt & AMS & $3,720 \pm 30$ & 2,200 to 2,030 \\
\hline L-XIII & E 704926/N 4023574 & $2.590-2.610$ & Charcoal dust & & Cancelled & Cancelled \\
\hline L-XIII & - & $2.960-2.985$ & Charcoal dust & & Cancelled & Cancelled \\
\hline L-XIII & - & 6.660 & Charcoal & AMS & $2,210 \pm 30$ & 381 to 196 \\
\hline L-XIII & - & 7.370 & Peace of wood & & Cancelled & Cancelled \\
\hline L-XIII & - & $9.470-9.500$ & Charcoal & & Cancelled & Cancelled \\
\hline L-V & E 706543/N 4023668 & $5.270-5.310$ & Organic clay & & Cancelled & Cancelled \\
\hline Öner L-1995-01 & & $\sim 6$ & & & $3,880 \pm 50$ & \\
\hline
\end{tabular}

ried out on core L-1995-01 by Öner (1999) and by our own analysis of core L-XII at a depth of $9.05 \mathrm{~m}$ beneath ground as part of the ARTEMIS programme. The results of the two datings made on samples taken from sediment lying just below the tephra are, respectively, 3,880 $\pm 50 \mathrm{BP}$ and $3,720 \pm 30 \mathrm{BP}$ (not calibrated datings, Table 1).

Near the shrine, the profile of electrical resistivity of the sediments confirmed the presence of a palaeochannel lying in front of the Letoon site. Results show it to be of medium electrical resistivity, mainly due to the presence of water and the porosity of the sediment. Sampling from core L-Ibis carried out at a later date, confirms this assumption. Beyond the depth of $2.9 \mathrm{~m}$, this core contains sands, gravels and blunt pebbles typical of the major riverbed load of a main channel. In addition, since samples L-XIII and L-VII, obtained from either side of core L-Ibis, do not contain this type of sediment, it is probable that the channel used to run in the place where LIbis is situated. Apart from the question of the palaeochannel, core L-VII (Fig. 2) provides the soundest information about the close environs of the shrine. The mixture of grey clay and sand found at a depth between 5.2 and $7 \mathrm{~m}$ is proof of the presence of lagoon dynamics which appeared after the growth of the bar that was to gradually close in the bay. At a later date, the transforma- tion of the lagoon into shallow marshland led to the formation of a thick layer of grey clay ranging from 2.8 to $5.2 \mathrm{~m}$. Drilling in a N-S transect carried out at the archaeological site by Öner (1999), as well as cores L-XVII, L-XIV and L-XV, reveal that the part of the plain extending south of the Letoon hill was wet, even after 3,300 cal. BP.

\section{Discussion}

At the beginning of the Holocene, an eustatic rise was flooding the downstream part of the Eşen Çayı which has now become the plain. Continental deposits on the margins of the bay built up an alluvial cone nowadays eroded into terraces at the present site of Xanthos. These early continental deposits at the bay are thought to date from the end of the Pleistocene, corresponding to the phase of intense erosion which took place during Late Glacial Maximum (Bousquet \& Péchoux 1984, Öner 1999). The hill of the Letoon site appears to have immediately be part of the alluvial plain as shown by drillings carried to the north of the plain: these drillings indicate that the limestone bedrock is only at a short distance - 2.4 $\mathrm{m}$ above the present-day sea-level - and is not covered in marine or lagoon sediment. In addition, by applying a $2.5 \mathrm{~m}$ altitude step between 
0 and $15 \mathrm{~m}$ to SRTM data, the picture of earlier deltas appears, encompassing the whole hill at the Letoon site (Fig. 3).

After the post glacial transgression had achieved its maximum level towards 6,000 cal. BP (Kelletat 2005), an offshore bar began forming, fed by a longshore drift as well as swell gathering up detritus matter previously deposited there by the rivers. The progressive closure of the bay caused by the development of a coastline spit is thus thought to have allowed a lagoon system to develop. This early spit must have been relatively mobile, allowing marine intrusions to deposit sea sands in the lagoons. The gray clay seems to be characteristic of a marshy area, the transitional phase between lagoon and alluvial plain in the process of progradation. But the very low quantity of organic matter in this clay suggests that marine waters could still, at the time, enter in that environment characterised by low- energy dynamics. Just before the eruption of the Santorini volcano in 3,300 cal. BP, the marine bay had been replaced by a lagoon system and the progradation of the delta was at an advanced state. Continental deposits gradually piled up behind the offshore bar, fed by increasingly stable marine deposits; the landscapes acquired continental-like characteristics. Gradual alluviation pushed the marshy areas towards the edge of the lagoon, which was gradually shrinking. It is thus in a landscape composed of lagoons and marshes that the shrine came into existence.

This echoes the legend according to which the shrine was built at the spot where a spring thrust itself up from a little limestone island (des Courtils 2003). Indeed, ancient texts and mythology paint the same picture of a watery landscape. Volume II, book VI of Ovid's Metamorphoses recounts that Leto, pursued by Juno, tried to slake her thirst in a pool lying in this site. Some of the peasantry

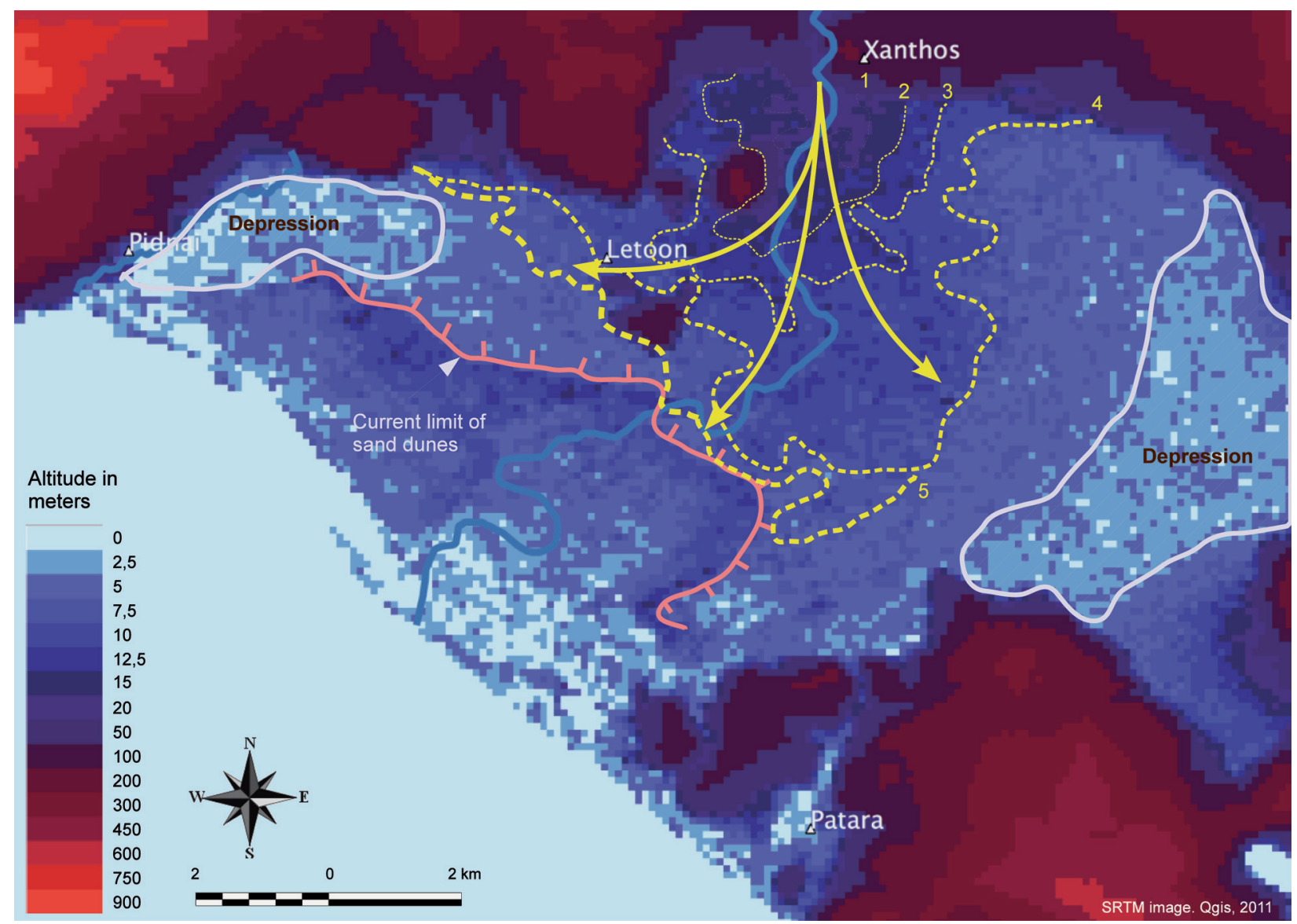

Fig. 3. Image of the first Eşen Çayı deltas, realised from SRTM data.

Dashed lines 1-5: Apparent borders, in the micro-topography, of former deltas (lines number 1 and 2 are the limits of the remains of an alluvial fan composed of fluvial pebbles, today eroded in terraces (Bousquet \& Péchoux 1981, Bousquet \& Péchoux 1984, Öner 1999); line 4 is the limit of the remains of the delta at 2,000 BC (Bousquet \& Péchoux 1981). Yellow arrows: directions of the delta progradation. 
sought to impede her endeavour, and the goddess wrought her revenge by changing them into frogs. In this context, the shrine of Letoon was faced with two environmental constraints: the continual presence of water due to karst processes, and increasing alluviation from the time when a branch of the Xanthus made its appearance in the area. In conditions such as these, the Letoon could be accessed in different ways: light craft from the sea could cross the offshore bar at Pidnai, where the mouth of a little river is situated, and then ply their way upriver to the shrine via the lagoon and a branch of the Xanthus. The shrine could also be reached from Xanthos by going down river (Strabo, Geography, Book 14). The Great Sea Stadiasm (Stad. Mar. Magn., 247, Arnaud, 2009) indicates, indeed, that the Xanthus river was navigable (Roelens-Flouneau 2011). While the hill of the Letoon shrine could never strictly speaking at any time have been called an island, its watery surroundings isolated the shrine pretty efficiently from the rest of the plain. Isolation, with no easy access and vulnerability to land and marine dynamics must have been the factors which encouraged the inhabitants to erect their shrine on this site (Le Roy 1984).

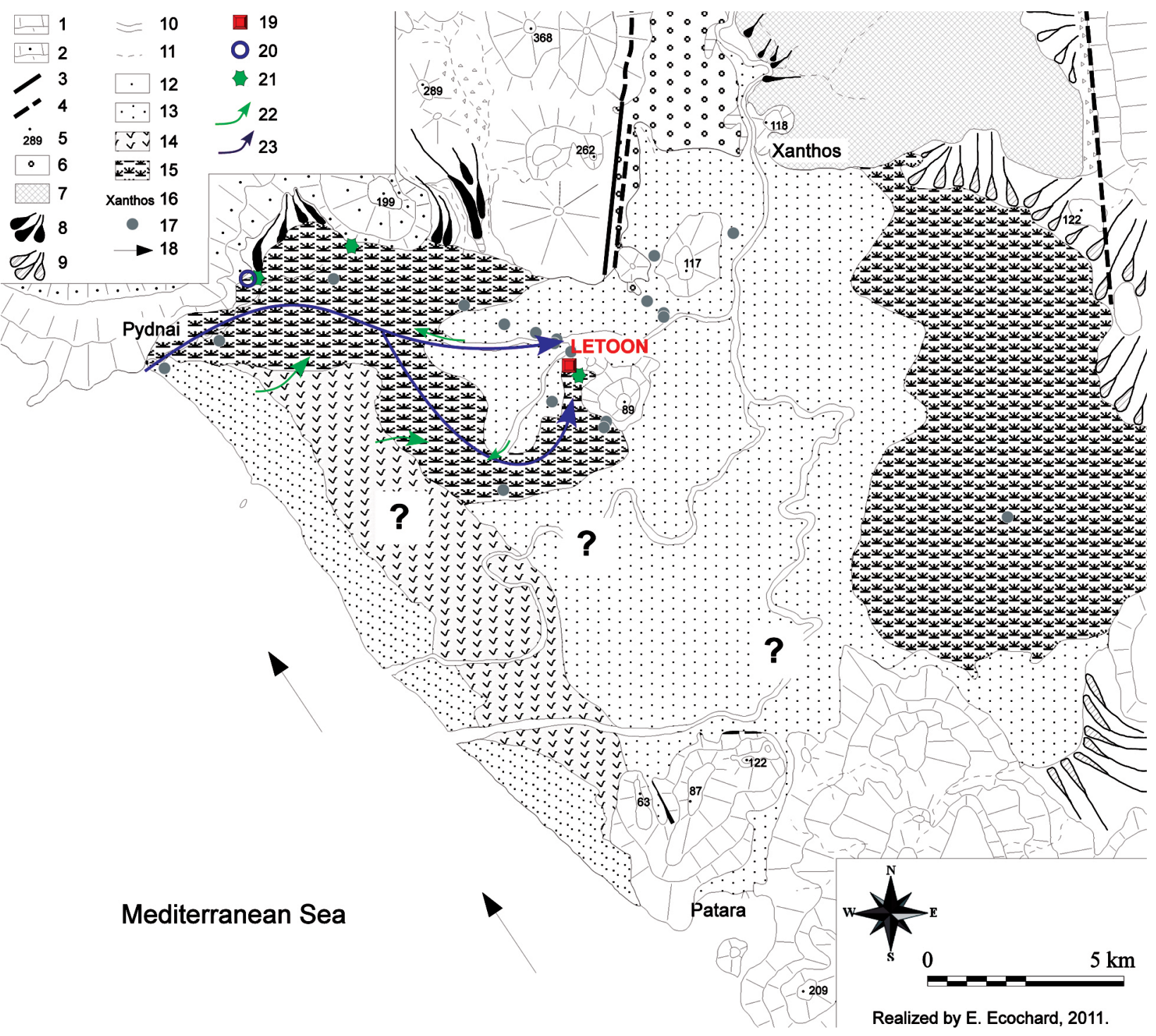

Fig. 4. The plain and lagoons at the time of the occupation of Letoon shrine.

1 - Micro-fractured limestone; 2 - Undifferentiated limestone; 3 - Visible fault; 4 - Hidden fault; 5 - Spot height; 6 - Pliocene lacustrine deposits; 7 - Mio-pliocene conglomerates: old terraces; 8 - Pleistocene dejection cones; 9 - Dejection cones of the end of Pleistocene; 10 Permanent streams; 11 - Intermittent streams; 12 - Palaeo-channels; 13 - Holocene alluvial deposits; 14 - Coastal sand deposits; 15 - Sand dunes; 16 - Swamps; 17 - Archaeological sites; 18 - Continental drift; 19 - Letoon shrine; 20 - Lycian harbour?; 21 - Springs; 22 - Dynamics closing the lagoon system; 23 - Hypothetical water ways to join Letoon. 
It thus emerges from this research first that the ancient peoples made use of the environmental constraints of the site upon the Letoon hill to enhance the religious value of the shrine, thus conferring a symbolic dimension upon the environment. Secondly, as has been shown, the landscape, viewed from the hill of the Letoon shrine by the inhabitants of the plain during the Hellenistic and Lycian periods, was very different to today's scenery (Fig. 4). In place of the marshy delta and the lagoons, there is now a multitude of greenhouses devoted to the growing of winter tomatoes. Interest in these two discoveries can be raised at the Letoon site itself by making them available to the general visiting the shrine. There is a growing demand for this type of information, on the part of the general and the authorities. Turkey is a case in point, with the Turkish Ministry of culture calling for suggestions about how to boost the tourist appeal of these sites.

\section{Management of an archaeo-geomorphosite}

Fouache \& Rasse (2009) employ the term geoarchaeosite to describe archaeological sites located on a geomorphosite (as defined by Reynard \& Panizza (2005), as the Mont-Saint-Michel in France or the site of Uluru in Australia. We propose here the term of archaeo-geomorphosite to define a geomorphosite with archaeological interest: historical and archaeological questions prompted geomorphological studies in the plain of Xanthos. The concept of geomorphosite and consequently of archaeo-geomorphosite crosses over disciplines and has a global character. Thus, they are very useful to link past, present and future processes. They have also a pragmatic application in the popularisation of scientific results and the management of the sites.

The issues involved in raising public interest in geomorphological data are first and foremost scientific (Reynard \& Panizza 2005, Panizza \& Piacente 2009). What is required is to establish the scientific relevance of a piece of geoarchaeological research for an overall understanding of the processes at work and the progradation mechanisms of the deltaic plains of the eastern Mediterranean (Reynard et al. 2007). Another issue is the improvement of the tourist appeal of these sites in order to cater for the general public's growing interest in environmental dynamics. Granted, it is seldom an informed interest even when on a visit to a place where the upheaval of the landscape has been considerable, for example Olympus (Fouache \& Pavlopoulos 2011), where the original site had completely vanished below $6 \mathrm{~m}$ of alluvium. The environmental context of Letoon possesses a historical and cultural significance since it has shaped the history of the shrine in a significant manner. Its cultural value is all the more significant as the archaeological sites of both Letoon and Xanthos are inscribed on UNESCO's World Heritage list. In order to be accessible to tourists, the appeal of this geomorphological heritage must be enhanced by helping visitors to imagine the environmental context as it appeared to ancient peoples and by explaining the geomorphological dynamics that the Letoon shrine had to cope with. It is essential to make use of the natural records composed of sediment samples and bring them into contact with archaeological and literary sources. The two sites of Xanthos and Letoon are under the management of the Turkish archaeological authorities, who are subject to the obligations laid down in the UNESCO listing. In addition, there is a partnership with a scientific mission financed by the French Ministry of Foreign Affairs, who are responsible for the organisation of research at the site. Within the framework of this partnership, the Turkish authorities have asked for the results of this research to be promoted as a tourist attraction and our own approach in this paper answers this request. The two sites are already adequately equipped for the reception of visitors in quest of archaeological and historical information (structured visit, explanatory brochures, charts): the first stage of any popularisation, i.e. the communicating stage - accessibility, panels on the roads, etc. - already began (Davallon 2006). Here they are privileged places for the popularisation of ideas (Sellier 2009). So the organisational framework is already in existence and this will facilitate the launching of an image boosting campaign. An improvement in the promotion of these archaeological sites, if supported by local political actors, will without a doubt produce economic dividends (Prud'homme 2008). The communities 
in the plain to which the sites belong will perhaps find it possible to diversify their economy a little more, based as it is today almost exclusively on the growing of winter tomatoes and seaside tourism. Today, in the context of the plan for 20072013, the Tourism Ministry of Turkey is trying to develop cultural tourism in order to reduce the share of seaside tourism in this sector. Indeed, the growth of coastal tourism in the 1980s left a range of accommodation disproportionate to the actual number of tourists (Mallet 2007). This is notably the case in Patara, southeast of the plain. The economy of the plain could take advantage of theses accommodation infrastructures in promoting cultural tourism, with the help of local public transports. Prud'homme (2008) has also shown that between two seaside resorts, the tourist will choose the one which, in addition to the beaches and sunshine, offers proximity to heritage items.

It is essential to help visitors realise that the landscape of Antiquity was very different to the scenery at the shrine today. Sightseers with an interest in history and archaeology should be brought to understand that the history of the shrine cannot ignore the history of its environment. The plain of Xanthos may be considered as a testimony of an history combining environmental and human factors. But understanding this testimony is very difficult for most visitors, who need a staging to seduce them (Bringer \& Toche 1996). The visitor is to be extracted from his daily life and inserted in another spatiotemporal context (Cayla et al. 2010). Bringing to light a heritage involves three transformations (Davallon 2006); the success of this process lies on adequate visibility and an easy access to the object popularised (Jacobi 1986, Jacobi \& Schiele 1988, Summermatter 2003). Several types of educational material could be provided for this purpose (Sellier 2009). Written information freely available to visitors at the archaeological site is the simplest and quickest way of achieving this aim. There could for example be explanatory charts placed at key observation points as well as in places worthy of specific commentary. The information displayed on these charts could be completed by a leaflet signposting direction for a visitor trail, based on a clear and detailed plan of the site. It would be best for the trail to begin at the western entrance of the shrine, explaining to sightseers that people probably used to arrive at the shrine by water, following a branch of the river. The paved way could then be taken as far as the temples and the spot where the spring is thought to have gushed. The leaflet could also include explanations and suggestions about where to halt at particular charts.

The charts and/or leaflets could include photographs of the attractive views to be had from the site. These plates might be provided with commentary and further enhanced with drawings outlining the differences between the scenery then and now. Explanations could be added about the ways and means used to reconstruct these landscapes (geophysical prospection, sedimentological analysis), along with a definition and an account of the geomorphological processes at work in the plain and that led to the sinking of the site into water and alluvium (definitions of karst resurgence, groundwater upwelling, alluviation, and so on). While the promotion of the geomorphological heritage of the plain of Xanthos will focus primarily on the Letoon site, the city of Xanthos, perched on its rocky promontory, nevertheless offers an attractive point of view over the levels as a whole.

The charts suggested here are will based on themes, each dealing with a particular subject, combining different approaches, depending on the fields of research involved in the topic. The presentations are organised first of all so as to situate the viewer, and this is why the archaeological plan of Letoon appears top right on all of the charts along with the legend "You Are Here" indicating the whereabouts of the chart and therefore of the visitor at the site. The middle of each chart focuses on a general introduction to the theme dealt with and sends the reader to detailed explanations or examples provided down each site. Research is displayed subject by subject (archaeology, epigraphy, literature, geography and geomorphology), so as to show viewers that the historical reconstruction spread out before them is the result of collaboration between different fields of research (Fig. 5). Emphasis is also laid upon the multi-disciplinary dimension by means of cross-references linking the boxes together. The organisation of each chart into different boxes devoted to the contributions of the various fields of research is also of great help in 
defining and demarcating the material each deals with.

The first chart aims to provide commentary upon the ancient gateway to the shrine. Its main purpose is to make the visitor realise that the present entrance to the archaeological site is not the one that was used in Antiquity. It then goes on to raise the question of access. How would people have reached the shrine? On foot? By boat? Aspects of methodology are also discussed, for instance the use of a coring device as a tool in geophysical prospection, allowing the reconstruction of palaeoenvironments. In the part devoted to geomorphology data, the chart describes the stages in the scientific process, beginning with the sampling of sediments on site, followed by their description and analysis in the laboratory, ending with their interpretation. The second chart is devoted to the spring that led to the erection of the shrine, showing how a geomorphological process - a karst resurgence - was put to cultural and religious use. In this context, the aim of the box entitled Geological and geomorphological data is to explain why a spring made its appearance at the Letoon site in the first place: the demonstration makes use of the geological map of the catchment area of the Xanthus on a scale of 1:500,000 along with a drawing of a karst relief (Şenel 1997a, b). This box is also a means of insisting on the difference between geology and geomorphology, subjects that are all too often confused in the minds of the general public. This is why the geological context - in this case the overriding presence of Jurassic limestone - partly explains the forms of the relief - in this instance the karst, forms which belong to the domain of geomorphology. Literary sources are in turn used in order to demonstrate the symbolical value attached to the resurgence and deriving from mythology, while archaeological sources uncover the architectural evolution of the edifices erected in honour of the spring (Fig. 5). The third chart delivers a more general commentary upon the evolution of the landscape around the shrine, from the vantage points of the terraces lying just below the excavation centre. The specific aim of this chart is to demonstrate

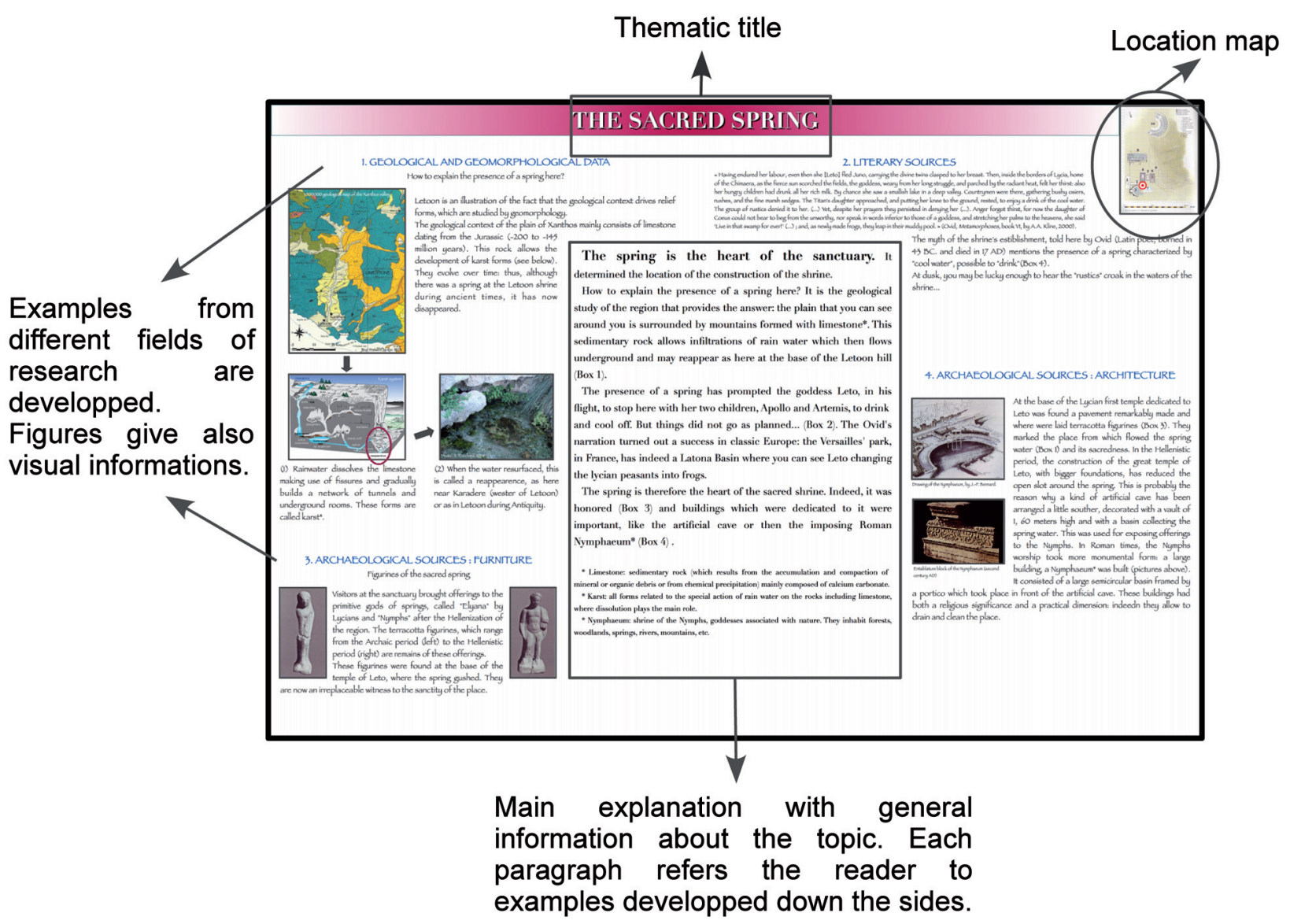

Fig. 5. General organization of charts proposed for the archaeological site of Letoon. 
the link between the history of the Letoon site and the evolution of the landforms in its environs. The display is somewhat different from the other two previous charts. The focal here point is based on a central chronology starting roughly in $4,000 \mathrm{BC}$ in order to deal with the environment of the hill at the Letoon site as it used to be at the height of the eustatic rise. The different contexts of various landscapes are portrayed within five boxes, ranging from the marine bay to the development of intensive farming introduced during the second half of the $20^{\text {th }}$ century. The chronology in the centre aims to help viewers situate themselves in the time scale. This is why the stages of permanent settlement of the plain are clearly indicated, first between the $7^{\text {th }}$ century BC and the Middle Ages, then from the $19^{\text {th }}$ century onwards. The chronological data provided cover the whole of Antiquity, in particular the various periods of domination that the plain was subjected to - Persian, Greek, Roman - so that visitors can understand the combinations of different time scales in the plain's history. In this way, the ancient settlements and the building of the shrine seem like mere afterthoughts in the long history of the plain's formation. This third chart is intended as a summary of the geoarchaeological research carried out in the area.

\section{Conclusion}

Thanks to geoarchaeological multidisciplinary approach, reconstructions of past landscapes can be provided by making use of different sources, whether geomorphological and sedimentary or archaeological and literary. We now know that the sites of Xanthos and Letoon were erected and occupied in a landscape dominated by lagoons and marshes, and this raises a question about what means of communication were used to link the two sites together, and also to the rest of the Lycian area. The plain of Xanthos is an illustration of the fact that mobility of landscapes encouraged ancient societies to adapt to the constraints imposed upon them by the landscape, and also to exploit them with pragmatic or symbolical intentions. Raising awareness of the value of this research the site of the Letoon shrine by means of explanatory charts, is a means of showing to a wider public the interest of palaeoenvironmental studies and the role they can play in historical and archaeological problem-solving. The gains to be made by boosting the touristic appeal of palaeoenvironmental and palaeogeographical data obtained from the surroundings of archaeological sites are potentially of great significance to the economy and society. While it is highly likely that the situation will not be long in panning out along the edges of the Mediterranean basin thanks to the great wealth of date already obtained, on a world scale the potential is even greater, notably in World Heritage sites listed by UNESCO. The development across the continents of research devoted to the links between human intervention and environmental dynamics is continually increasing this vast potential (Martini \& Chesworth 2011).

\section{Acknowledgements}

We gratefully acknowledge Mrs Frances MacFarlane and Mrs Cécile Fouache for the English translation of this paper and to the ANR EUPLOIA and the French Ministry of Europeans and Foreign affairs for the financial support.

\section{References}

Arnaud P., 2009. Notes sur le Stadiasme de la Grande Mer (1): La Lycie et la Carie. Geographia Antiqua, 18: 165-194. Arrian, 1976. Anabasis Alexandri, Vol. 1, book 1, Harvard University Press, Cambridge, Massachussets, Loeb Classical Library.

BEAUFORT F., 1818. Karamania, or a brief description of the South Coast of Asia Minor and of the remains of Antiquity with plans, views, Ec collected during a survey of that coast, under the orders of the Lords commissioners of the admiralty, in the years 1811 \& 1812, R. Hunter, London, 309 p.

Bousquet B. \& PÉCHOUX P.Y., 1981. Evolution géomorphologique des escarpements du Taurus lycien et des bordures du fossé du Xanthe (Turquie). Méditerranée, 1: 3-11.

Bousquet B. \& Péchoux P.Y., 1984. La plaine du Xanthe (Turquie), contraintes physiques et aménagements. Actes du $106^{\mathrm{e}}$ congrès national des sociétés savantes, Perpignan, 1981: 33-44.

Bringer J.P. \& Toche J., 1996. Pratique de la signalétique d'interprétation, Montpellier, ATEN.

Brown A.G., 1997. Alluvial Geoarchaeology: Floodplain Archaeology and Environmental Changes. Cambridge University Press, Cambridge.

Brückner H., VötT A., Schriever A. \& HANdl M., 2005. Holocene delta progradation in the eastern Mediterrane- 
an - case studies in their historical context. Méditerranée, 1: 95-106.

Cayla N., Hoblea F. \& Gasquet D., 2010. Guide des bonnes pratiques de médiation des géosciences sur le terrain. Géologie de la France, 1: 47-55.

DAVALlon J., 2006. Le don du patrimoine. Une approche communicationnellle de a patrimonialisation, Lavoisier, Paris.

Des Courtils J., 2003. Guide de Xanthos et du Létôon. Ege Yayınları, Istanbul.

Fellows C., 1840. An Account of Discoveries in Lycia being A Journal Kept During a Second Excursion in Asia Minor. John Murray, London.

Fellows C., 1852. Travels and researches in Asia Minor, more particulary in the province of Lycia. L. Murray, London.

FouAche E., 1999. L'alluvionnement historique en Grèce Occidentale et au Péloponnèse, Athènes. Bulletin de correspondance hellénique, suppl. 35.

FouACHE E. (ed.), 2003. The mediterranean world: Environment and History. Elsevier, Paris.

Fouache E. \& Pavlopoulos K., 2011. The interplay between Environment and People from Neolithic to Classical Times in Greece and Albania. In: Martini I.P., Chesworth W. (eds.) Landscapes and Societies. Springer: 155-166.

FouAche E. \& Pavlopoulos K. (eds.), 2005. Sea Level Changes in Eastern mediterranean during the Holocene - Indicators and Human Impacts. Zeitschrift für Geomorphologie, Supplement Volume, 137: 1-193.

FouAche E. \& RAsse M., 2009. Archaeology geoarchaeology and geomorphosite managment: towards a typology of geoarchaeosites. In: Reynard E., Coratza P., Regolini-Bissig G. (eds.) Geomorphosites. Springer: 213-224.

Herodote, 1932. Histoires, book I, Belles Lettres, Paris.

ЈАСов J.P., 1995. Le site archéologique. Un dialogue entre la culture et la nature ? In: Patrimoine culturel, patrimoine naturel, colloque 12-13 décembre 1994, Paris, La Documentation française.

JАСові D., 1986. Diffusion et vulgarisation. Itinéraires du texte scientifique. Les Belles Lettres, Paris.

JACOBI D. \& SCHIELE B., 1988. Vulgariser la science: le procès de l'ignorance. Chap Vallon, Seyssel.

KAYAN I., 1999. Holocene stratigraphy and geomorphological evolution of the aegean coastal plains of Anatolia. Quaternary Science Reviews, 18: 541-548.

Kelletat D., 2005. A Holocene Sea Level Curve for the Eastern Mediterranean from Multiple Indicators. Zeitschrift für Geomorphologie, suppl. 137: 1-9.

Le Roy C., 1984. Le Létôon de Xanthos en Lycie (Turquie). La lutte d'un sanctuaire contre l'évolution du milieu naturel. Bulletin de l'Association des Géographes français, 499: 41-44.

Mallet L., 2007. Le tourisme en Turquie: de la manne financière aux changements de mentalité. Hérodote, 4: 89-102.

Martini I.P. \& Chesworth W. (eds.), 2011. Landscapes and Societies. Springer.

ÖNER E., 1999. Letoon ve çevresinde (Eşen çayı deltası) paleojeomofolojik araştırmalar. Ege Coğrafya Dergisi, 10: 51-82.

Ovide, 1928. Les Métamorphoses. Tome 2, book 6. Belles Lettres, Paris.
Pelfini M., Brandolini P., Carton A. \& Piccazzo M., 2009. Geotourit trails: a geomorphological risk-impact analysis. In: Reynard E., Coratza P. \& Regolini-Bissig G. (eds.) Geomorphosites. Springer, 131-144.

Panizza M. \& Piacente S., 2009. Cultural geomorphology and geodiversity. In: Reynard E., Coratza P., Regolini-Bissig G. (eds.) Geomorphosites. Springer: 35-48.

Plutarque J.B., 2002. Conduites méritoires des femmes. Oeuvres morales. Tome 4. Belles Lettres, Paris.

PruD'HOMme R., 2008. Les impacts socio-économiques de l'inscription d'un site sur la liste du patrimoine mondiale: trois études. Note préparée à la demande du Patrimoine mondial de l'Unesco.

Rapp G. \& Hill C., 1998. Geoarchaeology: The Earth-Science Approach to Archaeological Interpretation. Yale University Press, London.

Reynard E., Fontana G., Kozlik L. \& Scapozza C., 2007. A method for assessing «scientific» and «additional values» of geomorphosites. Geographica Helvetica, 3: 148158.

Reynard E. \& Panizza M., 2005. Géomorphosites: définition, évaluation et cartographie. Géomorphologie: relief, processus, environnement, 3: 177-180.

Roelens-Flouneau H., 2011. Remarques sur la navigabilité des fleuves d'Asie mineure dans l'Antiquité. A paraître dans la publication des journées d'études sur les fleuves d'Asie mineure organnisée à Arras en 2010-2011.

SelLier D., 2009. La vulgarisation du patrimoine géomorphologique: objets, moyens, perspectives. Bulletin de l'Association des Géographes Français, 1: 67-81.

Spratt T.A.B. \& Forbes E., 1847. Travels in Lycia, Mylias, and the Cibyratis. John Van Voorst, Londres, 2 vol., 302 and $332 \mathrm{p}$.

Strabo, 1929. The geography of Strabo. Vol. 6, book 14. The Loeb classical library, Londres.

Summermatter N., 2003. Quelques réflexions sur les techniques scripto-illustratives utilisées dans les brochures relatives aux itinéraires didactique. In: Reynard E., Hozmann C., Guex D. \& Summermatter N. (eds.) Géomorphologie et tourisme. Actes de la Réunion annuelle de la Société suisse de géomorphologie, Finhaut, 21-23 septembre 2001, Lausanne, Institut de géographie, Travaux et Recherches, $\mathrm{n}^{\circ} 24$.

ŞENEL M., 1997a. Türkiye jeoloji haristası 1:500,000. Fethiye - L8 Paftası haristas. Maden Tetkik ve Arama Genel Müdürlüğü, Ankara.

ŞENEL M., 1997b. Türkiye jeoloji haristası 1:500,000. Fethiye - M8 Paftası haristası, Maden Tetkik ve Arama Genel Müdürlüğü, Ankara.

TeXIER C., 1839-1849. Description de l'Asie mineure: Beaux-arts, monuments historiques, plans et topographie des cités antiques, par Charles Texier, Gravure de Lemaître., 3 vol., Firmin Didot Frères, Paris, 241, 266 and 332 p.

Vita-Finzi C., 1969. The Mediterranean Valleys: Geological changes in Historical Times. Cambridge University Press, Cambridge.

Zouros N., 2009. Geomorphosites within geoparks. In: Reynard E., Coratza P. \& Regolini-Bissig G. (eds.): Geomorphosites. Springer: 105-118. 